\title{
Openings
}

Previously published at www.cmaj.ca

I $\mathrm{t}$ is funny, really, to be sitting at a folding table, tucked just inside the bookstore at the mall on the Saturday morning of a long weekend. Most people are outside soaking up the too-short summer. The few who come into the mall glance quickly at me and scurry by, avoiding eye contact. I keep what I hope is a pleasant look on my face. I didn't agree to sign books because I thought that I'd sell many - I knew I wouldn't. I agreed to sit at this table (and three more like it in different parts of the city over the next few months) so that I could see what the experience is like. Perched in the corner, amidst the display of teen mags with the neon-bright pictures of the Jonas Brothers and impossibly skinny girls, I don't have very high expectations.

The book is In Our Hands: On Becoming a Doctor, an anthology of creative writing by Canadian physicians-in-training (Pottersfield Press, 2007). I was the lead editor, with Jeff Nisker, a physician at the University of Western Ontario in London, Ontario. We both have a passion for story as it lives in the health care community and in medicine. For years, Jeff and I have used story in its many forms as a way to engage students and to teach about such "soft" (and vitally important) things as empathy, compassion, reflection and connection. During those years I have been moved, privileged, annoyed, troubled and left speechless by the stories that I have been party to. The book was one way to get some of those voices and stories out into the broader community, to honour the work and struggles of the authors as they learned to be physicians and to, hopefully, contribute to the ongoing discourse about the nature of health care and medicine.

As the day rolls on, a steady trickle of customers comes into the mall. An assortment of people drop by the table to see what I'm selling. A few buy a book, the store manager asks me to sign

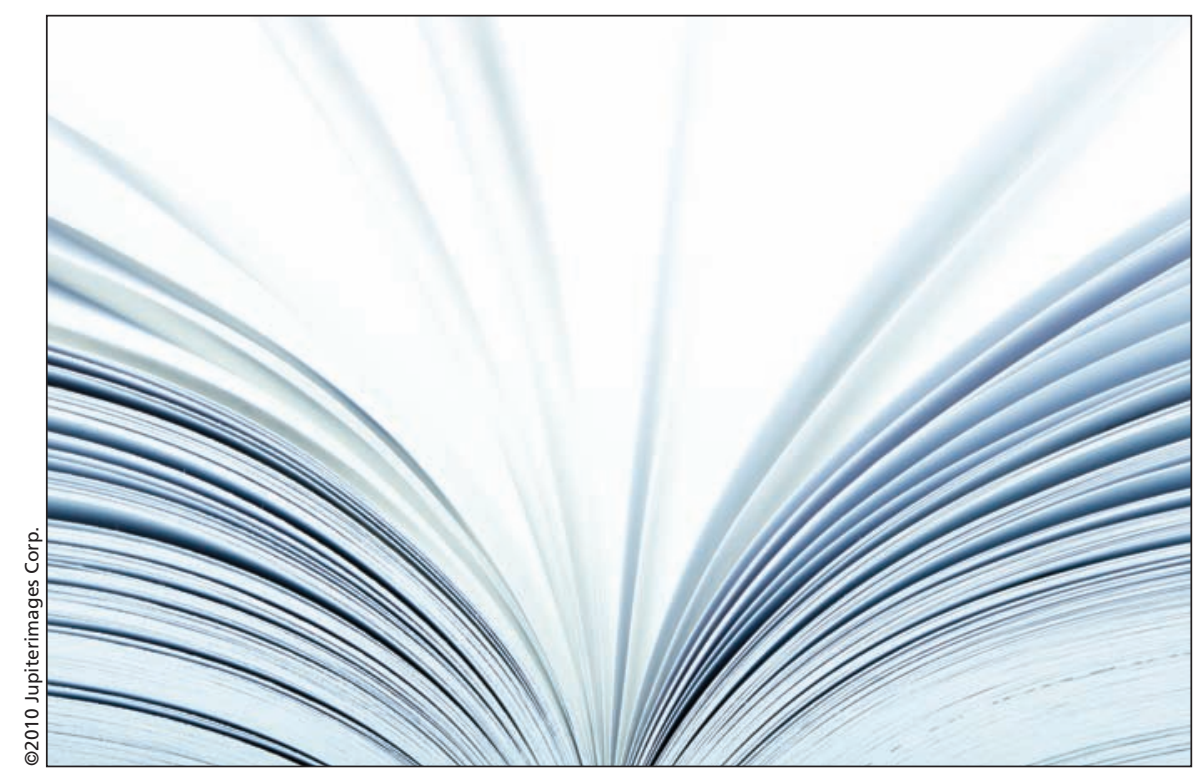

a pile, so there will be signed copies on hand after I've left.

It's almost 3:00 when I start to pack up. A man approaches: he's got an outdoorsy, Eddie Bauer kind of vibe about him. He's trim, tanned and has lovely thick grey curls.

"What's the book about?" he asks, sipping his coffee, peering through the bottom of his glasses.

I hold it up, read the title to him. "It's a collection of writings from Canadian medical students and residents."

He nods, takes another sip. "You a doctor?" he asks.

I chuckle, "Nope, just one of the editors of the book."

"Yeah, well, if you were a doctor, I don't know that I could talk to you," he says. I stop packing, to give him my attention.

"My wife died last year," he starts, "I've been a mess ever since." $\mathrm{He}$ perches on the edge of the table and lays out the story; it's one of sudden loss, of the rupture of his life. He's clearly angry at physicians and at the health care system. I want to listen, try to stay open, keep judgement at bay. After all, the books that rest on the table between us are about that, at least, about the need to tell a story and the need to have it received by someone else. For some, the way to return from the exile of suffering is to throw the thread of narrative out and to follow it home.

He finishes his story, coffee cup drained. He tells me that he's lonely and he misses his wife. I wish him the best and he heads back out into the sun. I pack up the books and go inside to the store manager to thank her and to say good-bye.

On the Saturday of the Labour Day weekend, I' $m$ at another mall, another bookstore, my third book signing. I am getting tired of this. This mall is busy and the parade of traffic flows by my small, white table.

Late in the morning, I notice an older couple, they've passed by the table a few times and their pace is slower than the rushing that is buoying them along. They are both tall and slender, he with khaki trousers and a cool white golf shirt, she with pale blue pedal pushers and a crisp white blouse. She wanders in my direction, smiles shyly. I return her smile.

"What is the book about?" she asks me, pointing to the books in front of me.

"A collection of writing by Canadian doctors-in-training," I tell her.

She takes one of the books from the pile. She leafs through it.

"I wish there was a book like this for patients," she says. She searches my 
eyes as she speaks. "I'd have a story for that book."

I'm used to this by now, the way that stories about health care invite people to tell their intimate stories. I value it, even though there is little, or nothing, I can do in response to their stories. There is value in the listening.

"Tell me the story," I invite. "If you'd like to."

She smiles over at her husband who has stayed on the other side of the concourse and is watching us. He smiles back at her. I wish I had another chair for her to rest on, but she tells me she's comfortable standing.

And she tells me her story. It's harrowing to hear, a tale of missed diagnoses, of belittling communication, of paternalistic behaviour and of feeling disrespected as she sought help for feeling so sick. When she was finally properly diagnosed, she learned that she had inoperable cancer and less than a year to live. She tells the story to me in even tones, sad now, rather than angry. She motions to her husband. "It's hardest on him," she says. "We've been together since we were just kids." He comes and stands beside her. She takes his hand.

"I am so sorry that happened to you," is what I say. It feels tepid.

She picks up the book again and asks me if there are any stories in it that will upset her; she'd like to avoid those ones, she says. I list a few that I think she may find difficult and she reaches into her purse for some money. I feel shy taking it from her, but she wants the book and tells me who to dedicate it to when I sign it.

Just as she's about to leave, she leans closer to me. "Thank you so much for letting me tell you my story," she says, "It feels wonderful to have someone hear it." She squeezes my hand and takes her husband's arm and walks away.

Linda E. Clarke MA

Writer, storyteller, narrative health care Halifax, NS

\section{More Humanities reading at www.cmaj.ca}

\section{Essays}

The Victorian medical show: Retired registered nurse Nancy Macleod has taken her collection of more than 200 pieces of 19thcentury medical memorabilia on the road. Dressed in period costume, she re-enacts the part of a "medical practitioner" of the era and "treats" their various ailments by bloodletting, amputation and the like. Barbara Sibbald BJ, Ottawa, Ont.

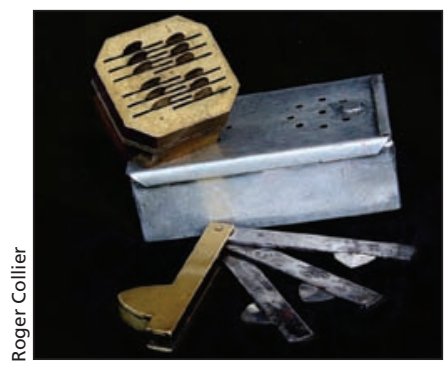

19th Century diary excerpt: Dr. Sigismund Finaly (1808-1876) of Hungary, an ancestor of one of the authors of this essay, provides an early lesson on the importance of patient autonomy, cultural sensitivity and mind-body interaction. - Shimon M. Glick MD, Robert Finaly MD, Beer-Sheva, Israel

\section{Books}

The Checklist Manifesto: How to Get Things Right, by Atul Gawande (Metropolitan Books/Henry Holt \& Company; 2009). Gawande argues that modern medicine, with its immense web of complexity, might find an unlikely hero in the checklist. He offers a convincing argument that is both intellectually sound and eloquently written. - George Puthenpurayil Jacob, London, Ont.

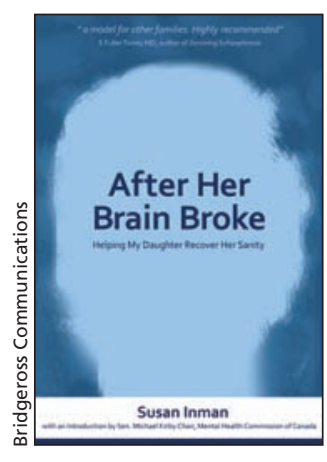

Poetry
Pitting Cherries, by Wynne Morrison MD MBE, Philadelphia, USA.

DOI:10.1503/cmaj.101259

After Her Brain Broke: Helping My Daughter Recover Her Sanity, by Susan Inman (Bridgeross Communications; 2010). Inman tells the story of how she and her husband struggled to understand and cope with their teenage daughter as her diagnoses changed from "just normal teenage rebellion" to bipolar illness to schizoaffective disorder. This book is well written, moving without being sentimental, informative without being pedantic. - Ellen Wiebe MD, Vancouver, BC 